\title{
Short Communication: Humans and the missing C-sink: erosion and burial of soil carbon through time
}

\author{
T. Hoffmann ${ }^{1}$, S. M. Mudd ${ }^{2}$, K. van Oost ${ }^{3}$, G. Verstraeten ${ }^{4}$, G. Erkens ${ }^{5}$, A. Lang ${ }^{6}$, H. Middelkoop ${ }^{5}$, \\ J. Boyle ${ }^{6}$, J. O. Kaplan ${ }^{7}$, J. Willenbring ${ }^{8}$, and R. Aalto ${ }^{9}$ \\ ${ }^{1}$ Department of Geography, University of Bonn, Meckenheimer Allee 166, 53115 Bonn, Germany \\ ${ }^{2}$ School of Geosciences, University of Edinburgh, Drummond Street, Edinburgh EH8 9XP, UK \\ ${ }^{3}$ KU Leuven - University of Leuven, Department of Earth and Environmental Sciences, Celestijnenlaan 200e, \\ 3001 Leuven, Belgium \\ ${ }^{4}$ Department of Earth and Environmental Sciences, University of Leuven, Celestijnenlaan 200e, \\ 3001 Heverlee, Belgium \\ ${ }^{5}$ Department of Physical Geography, University of Utrecht, Heidelberglaan 2, 3584 CS Utrecht, the Netherlands \\ ${ }^{6}$ School of Environmental Sciences, University of Liverpool, Liverpool L69 3GP, UK \\ ${ }^{7}$ Institute of Environmental Engineering, Ecole Polytechnique Fédérale de Lausanne, Station 2, \\ 1015 Lausanne, Switzerland \\ ${ }^{8}$ University of Pennsylvania, Department of Earth and Environmental Science, 240 S. 33rd Street, \\ Philadelphia, PA 19104-6313, USA \\ ${ }^{9}$ College of Life and Environmental Sciences, University of Exeter, Rennes Drive, Exeter EX4 4RJ, UK \\ Correspondence to: T. Hoffmann (thomas.hoffmann@uni-bonn.de)
}

Received: 9 June 2013 - Published in Earth Surf. Dynam. Discuss.: 24 June 2013

Revised: 31 October 2013 - Accepted: 6 November 2013 - Published: 26 November 2013

\begin{abstract}
Is anthropogenic soil erosion a sink or source of atmospheric carbon? The answer depends on factors beyond hillslope erosion alone because the probable fate of mobilized soil carbon evolves as it traverses the fluvial system. The transit path, residence times, and the resulting mechanisms of C-loss or gain change significantly down-basin and are currently difficult to predict as soils erode and floodplains evolve - this should be a key focus of future research.
\end{abstract}

1

A considerable fraction of human-induced carbon dioxide $\left(\mathrm{CO}_{2}\right)$ emissions due to fossil fuel combustion and land cover change is absorbed by the oceans and the terrestrial biosphere. Soils store about $80 \%$ or $2500 \mathrm{Pg} \mathrm{C}$ of the total carbon $(C)$ in the terrestrial biosphere, and thus contain three times more $\mathrm{C}$ than the atmosphere (Lal, 2004). Consequently, soil $\mathrm{C}$ represents a substantial and highly sensitive component within the global carbon cycle and small changes in the soil $\mathrm{C}$ may result in large changes of atmospheric $\mathrm{CO}_{2}$ at timescales of $10^{1}$ to $10^{3} \mathrm{yr}$.

During the last decade, research has highlighted the importance of vertical exchanges of carbon between the atmosphere, biosphere and pedosphere (e.g. Ruddiman, 2003).
Little attention was devoted to the full "life cycle" of the eroded minerals from soil to sea including the lateral fluxes of organic carbon (OC) associated with human-induced soil erosion. In many regions of the world, soils have increasingly been eroded (Wilkinson and McElroy, 2007), owing to increasing agricultural activity during the last few thousand years, with negative impacts on soil fertility and productivity as well as strongly increased lateral sediment-burden carbon fluxes. Therefore, sediment-burden carbon fluxes potentially provide an important, yet unknown, component in the global carbon cycle. As yet, lateral C-fluxes on hillslopes (Quinton et al., 2010; Starr et al., 2000; Van Oost et al., 2007) and in river channels (Aufdenkampe et al., 2011; Battin et al., 2008, 2009; Cole et al., 2007) (Fig. 1) have received little 


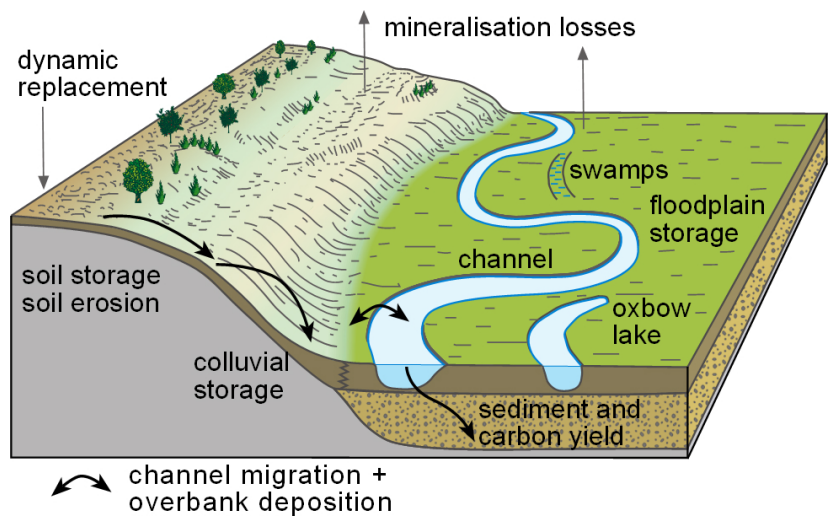

Figure 1. Storage compartments and lateral and vertical C-fluxes in agricultural landscapes.

attention, and their representation in contemporary carbon cycle models is rudimentary: soils are typically represented as spatially homogeneous and static entities, which does not reflect their dynamic nature in response to anthropogenic disturbance. Hillslopes are often regarded as simple engines that sequester or release carbon through soil formation and subsequent erosion. River channels are generally viewed as passive pipes that flush carbon from the hillslopes to the oceans (Battin et al., 2009), with floodplains that are mostly considered as wetlands that trap sediment and nutrients from the river, sustain productive riparian vegetation and hence induce higher $\mathrm{CH}_{4}$ fluxes (Petrescu et al., 2010).

Sediment mobilized in river catchments by the introduction of agriculture has important implications for lateral carbon fluxes in fluvial systems. Soil erosion and carbon emissions are tightly linked through OC-stabilization by organomineral associations, requiring a profound understanding of the coupling between sediment and OC-erosion, as well as transport and storage. Three key mechanisms determine the coupling between sediment and carbon fluxes: (i) OC fixation to surfaces of mineral particles eroded on hillslopes and transported in river systems, (ii) increased mineralization of OC due to aggregate breakdown during transport, and (iii) stabilization of OC through burial (Fig. 1) (Van Oost et al., 2007). While soil scientists, geomorphologists and geochemists generally agree these are all key mechanisms, markedly different assumptions have been made about their relative importance. This has resulted in an intense debate as the inter-relation of these key mechanisms decides the significance of erosion-induced terrestrial carbon as sink or source (Berhe et al., 2007; Lal and Pimentel, 2008; Van Oost et al., 2007): strong mineralization acts as an atmospheric $\mathrm{CO}_{2}$ source, while OC-fixation and burial provide a major atmospheric $\mathrm{CO}_{2}$ sink. Because erosion, transport and depositional processes change along the sediment and carbon transport path from hillslopes to large river systems, the relative contributions of erosion induced OC-fixation, mineralization and OC-protection through burial change over space and time. Recent studies have focused on decadal timescale perturbations to the C-cycle via soil erosion (Jacinthe and Lal, 2001; Ritchie and Rasmussen, 2000; Van Oost et al., 2007), yet it has emerged that sediments are stored on hillslopes and floodplains for several thousand years, meaning that humaninduced changes to sediment-driven carbon fluxes can be delayed and altered over millennial timescales (Hoffmann et al., 2009a; Van Oost et al., 2012). Accounting for the nonsteady-state C-dynamics along the flow path from hillslopes to river channels and then into the oceans is thus pertinent to understanding both the past and future global C-cycle. Here, we review the current understanding of sediment and carbon dynamics on hillslopes and in river channels and encourage an integrated view of long-term sediment-associated carbon dynamics.

\section{Hillslope erosion and deposition}

Hillslopes are major source areas of sediment and carbon. Estimates of global soil erosion on agricultural land vary between 28.1 and $150 \mathrm{Pg} \mathrm{a}^{-1}$. Most recently Quinton et al. (2010) estimated the total contemporary erosion rate (including water, tillage and wind erosion) at $35 \pm$ $10 \mathrm{Pg} \mathrm{a}^{-1}$, which corresponds to a carbon erosion rate of $0.5 \pm 0.15 \mathrm{Pg} \mathrm{a}^{-1}$. These rates change through time as a result of population density, cultivation techniques and climate (Hoffmann et al., 2009a; Notebaert et al., 2011; Trimble, 1999). Eroded sites are usually characterised by lower soil fertility, crop productivity and C-contents than non-eroded sites supporting the notion that soil erosion is a major source of atmospheric $\mathrm{CO}_{2}$ (Jacinthe and Lal, 2001; Lal, 2005; Victoria et al., 2012). Yet, OC-loss is partially balanced by OCinput through plants and fertilization and it may thus be argued that OC-fixation changes in concert with erosion rates at timescales covering the period of agriculture.

Estimates of soil and carbon erosion rates on regional to global scales in agriculturally developed river systems either rely on erosion plot studies or on measured sediment discharges. Plot studies, however, measure the amount of soil that is moved on the fields, and thus overestimate the "loss" of soils to river channels, which is only a small proportion of the eroded soil. In contrast, sediment discharges at river gauging stations estimate the sediment or OC-yield (efflux) that is transported beyond the gauging station, but do not quantify any sediment deposition upstream. Major flux differences found between these two approaches indicate that a large fraction of the detached soil is transported only a limited distance (Parsons et al., 2006) and that a substantial amount of sediment is stored at the foot of hillslopes: i.e. the transition between the hillslopes and the channels (Houben, 2008; Verstraeten et al., 2009). Thus, considering hillslopes simply as sources of sediment and carbon neglects (i) the differences between soil erosion and sediment yield (Dotterweich, 2008; Trimble, 1999; Verstraeten et al., 2009) 
and (ii) the complexity of the internal sediment dynamics at the hillslope scale (Lang and Honscheidt, 1999; Cerdà et al., 2012). This simplification can account for the major discrepancies in the current estimates of the effects of soil erosion: Lal (2005) indicate that $20-30 \%$ of eroded OC is released through erosion-induced mineralization, whereas Van Oost et al. (2007) derive an order of magnitude lower mineralization rates of only $\sim 2 \%$ based on ${ }^{137} \mathrm{Cs}$ inventories within fields.

During the last two decades, long-term sediment budgets (Hoffmann et al., 2010; Brown et al., 2009), which can account for some of the sources, pathways and sedimentary sinks, have increasingly shed light on the response of hillslope systems to human-induced soil erosion (Lang et al., 2003). These budgets provide an organizing framework to answer the following open research questions: How much eroded carbon is stored in colluvial sediments, and what are typical residence times of carbon and sediment on hillslopes? Sediment redistribution across hillslopes (as estimated by soil erosion plots) does not affect the downstream channel system, but does it have a significant impact on the global carbon cycle? How far must sediment be transported until it is depleted in carbon? Possible approaches to answer these questions are presented by Wang et al. (2010), who suggest OC-enrichment of exported sediment due to grain size sorting and the association of $\mathrm{OC}$ to fine grain fraction (e.g. clays), and by Van Oost et al. (2012) stating that $50 \%$ of colluvial OC is decomposed within $500 \mathrm{yr}$. Yet, major uncertainties on the role of the hillslope sediment dynamics in the global carbon cycle remain (Aufdenkampe et al., 2011; Brantley et al., 2011; Yoo et al., 2011).

\section{Fluvial transport and deposition}

Recent studies have highlighted the role of rivers (including small streams, lakes, artificial reservoirs and wetlands) not only in transporting the $\mathrm{C}$ exported from terrestrial ecosystems but also in metabolising and burying significant amounts of C (Aufdenkampe et al., 2011; Battin et al., 2008, 2009; Cole et al., 2007; Tranvik et al., 2009). Globally, rivers receive about $2.9 \mathrm{Pg} \mathrm{C}$ each year, a quantity that represents the differences between global annual terrestrial production and respiration (Tranvik et al., 2009; Aufdenkampe et al., 2011). A major part of this carbon is associated with sediments mobilized through surface runoff. Only a fraction of this carbon is transported directly into the oceans $\left(0.9 \mathrm{Pg} \mathrm{Ca}^{-1}\right)$ while the majority is mineralized or outgassed to the atmosphere $\left(1.4 \mathrm{Pg} \mathrm{Ca}^{-1}\right)$, or buried in lakes and reservoirs $\left(0.6 \mathrm{Pg} \mathrm{a}^{-1}\right)$ (Tranvik et al., 2009). Still, long-term Cburial in floodplains and subsequent outgassing are generally not considered (Battin et al., 2009; Cole et al., 2007; Tranvik et al., 2009) due to the limited availability of data on global floodplain extent, sedimentation rates, duration of inundation and gas exchange velocities between floodplains and the atmosphere.

First estimates of global C-burial on hillslopes and floodplains (Aufdenkampe et al., 2011) range between 0.5$1.5 \mathrm{PgCa}^{-1}$. These numbers are derived from the difference between global soil erosion (50-150 $\mathrm{Pg} \mathrm{C} \mathrm{a}^{-1}$ ) (Wilkinson and McElroy, 2007) and sediment delivery to the ocean (12.6 $\mathrm{Pg} \mathrm{a}^{-1}$ ) (Syvitski et al., 2005), which is multiplied by an average C-concentration of eroded and exported sediment $(\sim 1 \%)$ (Aufdenkampe et al., 2011). Although informative, these numbers are not direct measurements, and account for neither temporal storage nor remobilization within the fluvial system. More explicit representation of floodplains and their impact on the global carbon cycle is essential because floodplains represent a major depositional environment (Aalto et al., 2003; Hoffmann et al., 2007; Noe and Hupp, 2005; Verstraeten et al., 2009). Based on a Holocene sediment budget of the Rhine basin, Hoffmann et al. (2013) estimated that $1.1 \pm 0.5 \mathrm{PgC}$ is stored in the floodplains of the non-alpine part of the Rhine basin (i.e. $125000 \mathrm{~km}^{2}$ ), equivalent to a long-term OC-sequestration rate of 5.3 to $17.7 \mathrm{~g} \mathrm{C} \mathrm{m}^{-2} \mathrm{a}^{-1}$. While these rates are timeintegrated Holocene averages, several lines of evidence support a significant increase of organic-rich overbank deposition during the late Holocene (Hoffmann et al., 2009a; Verstraeten et al., 2009). Pre-human background rates of overbank deposition in the Rhine are $\sim 0.5 \mathrm{~mm} \mathrm{a}^{-1}$, corresponding to a C-sequestration of $8.3 \mathrm{~g} \mathrm{C} \mathrm{m}^{-2} \mathrm{a}^{-1}$. In contrast, maximum sedimentation rates during the last $300 \mathrm{yr}$ indicate at least an order of magnitude increase to $15 \mathrm{~mm} \mathrm{a}^{-1}$ or $166 \mathrm{~g} \mathrm{C} \mathrm{m}^{-2} \mathrm{a}^{-1}$. These high rates generally coincide with increased hillslope erosion resulting from agricultural intensification (Notebaert and Verstraeten, 2010; Hoffmann et al., 2009a).

High sequestration rates of $100 \mathrm{~g} \mathrm{C} \mathrm{m}^{-2} \mathrm{a}^{-1}$ associated with soil formation in freshly deposited overbank deposits (Zehetner et al., 2009) imply that a large fraction of floodplain OC is not the result of sediment-burden carbon fluxes, but represents in-situ OC-formation. These high rates are maintained during the initial $100 \mathrm{yr}$ after sediment deposition, and thus strongly conditioned by the input of fresh sediments that provide abundant mineral surface area for complexation of OC on timescales $>100 \mathrm{yr}$. As shown by studies on OC-burial in marine fans and shelves (Hilton et al., 2008; Galy et al., 2007), high sediment input not only favours OCsequestration, but also increases the burial efficiency of OC in marine deposits.

The residence time and the stability of $\mathrm{OC}$ in floodplains are strongly related to the geomorphological and hydrological floodplain dynamics, depending on the dominant grain size of floodplain sediments and the structure and age of riparian vegetation. High energy, non-cohesive floodplains of headwater streams are characterised by coarse sediments, mobile channels, open vegetation cover, and large groundwater fluctuations. The high sediment transport capacity causes 
a low storage potential, and thus short residence times of floodplain OC. In contrast, low energy, cohesive floodplains are characterised by stable channel banks with massive and cohesive overbank deposits, and dense vegetation coverage. These represent major sedimentary sinks that are able to store sediment-burden carbon for several thousand years (Battin et al., 2008). Further important links between geomorphic dynamics and floodplain OC include changes of the groundwater tables, hydrological connectivity and river incision caused by river engineering and land cover change (Hupp et al., 2009; Noe and Hupp, 2005; Osterkamp et al., 2012).

The comparison of the burial efficiency (given by the rate of OC-accumulation minus the oxidation of OC within the sink) in different depositional settings suggests that sequestration of OC within floodplains exceeds that of lakes, artificial impoundments and afforestation of catchments (Fig. 2). The ubiquitous prevalence of floodplains and their comparable burial efficiency to peats highlights both their importance and their insufficient representation within global C-budgets. Despite growing awareness of the multiple sources of floodplain OC and the feedbacks between sediment and vegetation dynamics in floodplains, quantitative understanding of the functioning of floodplains as $\mathrm{C}$-sources or sinks remains elusive, with specific implications for the global C-cycle are hardly considered.

\section{Towards integrated biogeochemical and geomorphological approaches}

Recently, major progress has been made in understanding land use and climate impacts on sediment dynamics through the study of Holocene sediment budgets (Hoffmann et al., 2010). These studies provided essential information on (i) the sensitivity of hillslopes and channel systems to environmental change (Notebaert and Verstraeten, 2010; Verstraeten et al., 2009); (ii) the storage, residence time and remobilization of sediment along the flow path (Houben et al., 2009; Hoffmann et al., 2007; Aalto and Nittrouer, 2012); (iii) the connectivity between hillslopes and channels (Verstraeten et al., 2009; Lang et al., 2003); and (iv) the resulting non-linear dynamics between soil erosion and sediment yield (Erkens et al., 2011; Van De Wiel and Coulthard, 2010). While longterm budgets portrayed changing sediment dynamics through time and are of great value to reconstruct variable sediment burden OC-fluxes, their potential is not yet fully exploited. This becomes apparent when comparing estimates of sediment-associated OC-erosion during the last $50 \mathrm{yr}$ with long-term OC-burial studies. In contrast to the limited impact of soil erosion on atmospheric-C during the last $50 \mathrm{yr}$ (Van Oost et al., 2007), terrestrial sediment storage presents an important long-term atmospheric C-sink (Fig. 3) (Hoffmann et al., 2009b; Van Oost et al., 2012). The discrepancies between short- and long-term OC-budgets and their implications highlight that mechanisms associated with changing

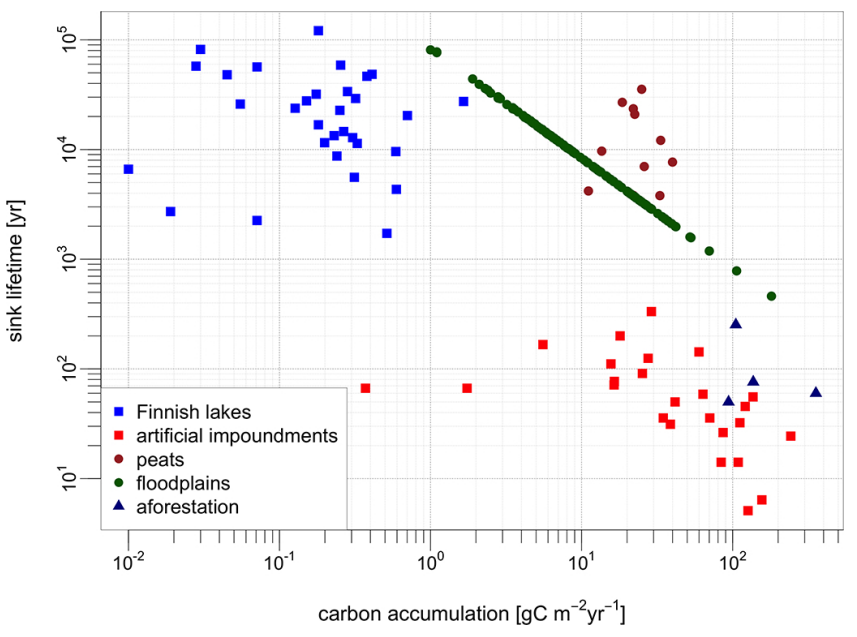

Figure 2. Lifetime versus sequestration rate of selected carbon pools. For details on data and calculations see Supplement.

conditions of OC-fixation and stabilization need to be considered more explicitly. These include the effects of changing hydrology, ecology (Osterkamp et al., 2012), and anthropogenically induced land cover change ALCC (Lechterbeck et al., 2009) during the Holocene. For instance, severe soil erosion in Mediterranean landscapes during the last Millennia changed soil covered regions into landscape of bare rock over large areas and thus resulted in almost irreversible changes of the ecological conditions (Fuchs et al., 2004; Lowdermilk, 1948). Dusar et al. (2011) and Marselli and Trincardi (2013), for instance, suggest that sediment yields in many Mediterranean landscapes declined during the last $1-2 \mathrm{ka}$ as a consequence of the widespread soil depletion. Of major importance with respect to future global C-cycle is the declining capacity of the remaining soil to replace eroded OC as the extent and severity of soil degradation and desertification increases (Lal, 2009). In addition, the decay of buried $\mathrm{OC}$ in depositional settings is decreasing under drier climatic conditions as projected for the future decades (Solomon et al., 2007). Furthermore, deforestation increases not only soil erosion and sediment flux into sedimentary sinks, but also transforms the morphology of river channels (Walter and Merritts, 2008). Changing channel morphology involves, for example, (i) transformation of floodplains from stable channels in cohesive deposits to coarse sediments and mobile channels, and (ii) transitions from higher to low groundwater levels with corresponding changes from stabilized floodplain OC to destabilization and emission of large amounts of organic $\mathrm{C}$ to the atmosphere.

These conceptual considerations highlight the influence of indirect links between geomorphological processes and OC-fluxes that act on century-to-Holocene timescales. We believe that the on-going discussion about whether anthropogenic soil erosion is a sink or source of atmospheric carbon will not be solved until we synthesize biogeochemical 


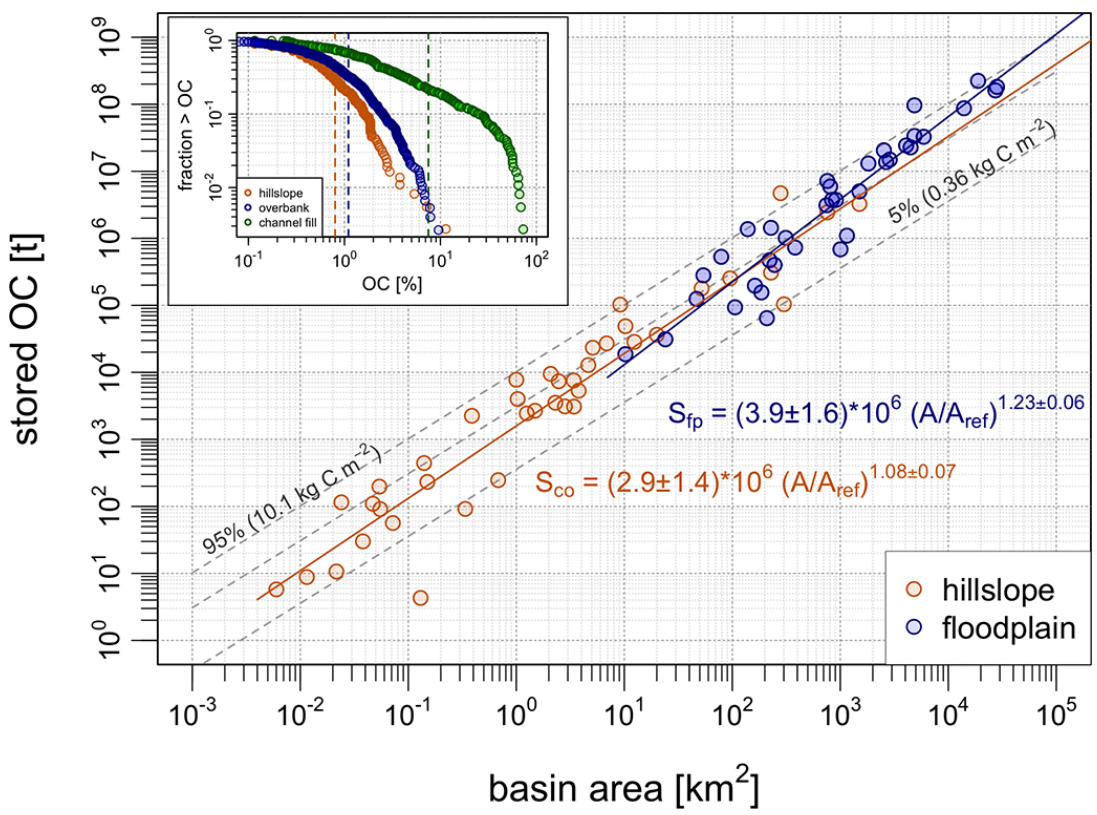

Figure 3. Holocene carbon storage on hillslopes and in floodplains as a function of basin size (Hoffmann et al., 2013). Lines represent predicted hillslope $\left(S_{\mathrm{co}}\right)$ and floodplain $\left(S_{\mathrm{fp}}\right)$ storage using power law regression with normalized basin area: $S=\alpha \times\left(A \times A_{\text {ref }}^{-1}\right)^{\beta}$. The scaling coefficient $\alpha$ represent OC-storage [t] at the reference basin area $\left(A_{\text {ref }}=1000 \mathrm{~km}^{2}\right)$ and mainly reflect the greater OC-concentration of floodplain deposits (i.e. overbank and channel fills) compared to hillslope deposits (see inset: cumulative frequency distributions of OCinventory from hillslope, and floodplain sediments). The scaling exponent of floodplain storage $\beta_{\mathrm{fp}}=1.23 \pm 0.06$ indicates a greater increase of floodplain $\mathrm{OC}$ with basin than hillslope $\mathrm{OC}$, which is given by $\beta_{\mathrm{co}}=1.08 \pm 0.07$ slightly larger than one. These results are in accordance with an increasing accommodation space for floodplain storage with basin size. For details see Supplement.

and geomorphological approaches, thereby properly considering the fate of mobilized $\mathrm{OC}$ as it travels from the hillslopes through the river network at corresponding timescales of $10^{\circ}$ to $10^{4} \mathrm{yr}$. Such detailed studies are increasingly feasible using improved techniques for high-resolution geochronology of colluvial and fluvial deposits over timescales for decades to millennia (Aalto and Nittrouer, 2012; Chiverrell et al., 2008; Hobo et al., 2010).

To put our estimates of hillslope- and floodplain-OC storage into perspective (Fig. 3), we extracted C-emissions as a result of ALCC for the Rhine basin from the global modelling scenarios described in Kaplan et al. (2011, 2012) (Fig. 4). Our sediment storage data indicates that hillslopes and floodplains could have sequestered an amount of OC similar to the cumulative $\mathrm{C}$-emissions from anthropogenic land cover change during the last $8000 \mathrm{yr}$. Thus, in this region, soil erosion associated with human-induced land-cover changes potentially offsets the effects of C-emissions caused by long-term ALCC. Furthermore, high accumulation rates and long residence times indicate that floodplains and peats represent the dominant terrestrial OC-sink, while OC-uptake in lakes, reservoirs and forests is limited due to either lower accumulation rates or shorter residence times in these pools (Fig. 2). Yet, the timescales of protection of eroded organic soil material are insufficiently understood (including the complex mechanisms of ensuing reburial and then fur- ther destabilization due to changing environmental conditions on hillslopes and in floodplains). Thus, whether anthropogenic soil erosion is a sink or source of atmospheric carbon is not dependent on hillslopes alone. Instead, the fate of mobilized soil carbon changes as it travels through the river network. The transit path and the resulting C-loss or gain dynamically changes and is complicated to predict as soils erode and floodplains evolve. In fact, hillslopes and floodplains are important components of the "boundless carbon cycle" (Battin et al., 2009), that introduce legacy effects into contemporary C-dynamics (Van Oost et al., 2012). Their functioning within the Holocene's boundless carbon cycle is heavily dependent on ALCC and catchment management, both of which require an appropriate understanding of changing environmental conditions on mineral sediments and associated carbon fluxes across spatial and temporal scales. A better accounting of hillslopes and floodplains (Fig. 3) as factors of global change demands integrated geomorphological and biogeochemical studies on long-term sediment-burden carbon fluxes under different environmental conditions (e.g. old vs. new world and temperate vs. semiarid climate). Erosion-induced soil degradation and decline in biomass production should also be considered when evaluating the OC-budget, particularly in regions of the world where long-term land degradation is observed. Such research is now technically possible. Potential benefits from the study 


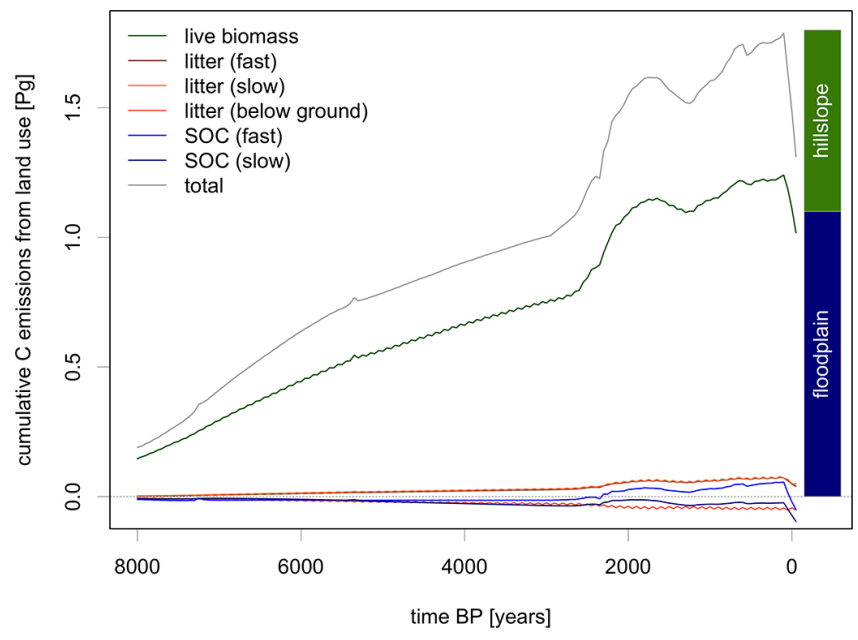

Figure 4. Cumulative carbon emissions as a result of anthropogenic land cover change in the non-alpine Rhine Basin. Emissions were calculated using the LPJ Dynamic Global Vegetation Model in the standard simulation using the KK10 anthropogenic land cover change described in Kaplan et al. (2011, 2012). Emissions accumulated steadily as a result of anthropogenic deforestation throughout most of the Holocene, with accelerated deforestation occurring during the Iron Age and Roman period around 500 BC-AD 500, followed by a period of land abandonment during the Migration Period, and accelerating deforestation during Medieval times. The period AD 1500-1900 is marked by relative stability in land use with little new deforestation emissions; during the 20th century land abandonment and afforestation lead to a strong uptake of carbon. Hillslope and floodplain storage are taken from Hoffmann et al. (2013) (compare Fig. 3).

of geomorphically coupled biogeochemical cycles would be substantial and help to (i) evaluate the wide-ranging implications of changing erosion and sediment dynamics for the global carbon budget, and (ii) assist policymakers to incorporate hillslopes and floodplains into catchment management strategies to mitigate climate change.

\section{Supplementary material related to this article is available online at http://www.earth-surf-dynam.net/1/ 45/2013/esurf-1-45-2013-supplement.pdf.}

Acknowledgements. This paper is a result of the open IGBPPAGES-PHAROS workshop "Sediment and carbon fluxes under human impact and climate change", which was held in July 2011 in Bern, Switzerland. We would like to thank IGBP-PAGES for the financial support of the workshop. Furthermore, funding was provided for T. Hoffmann through the DFG-SFB 806 "Our way to Europe".

\section{References}

Aalto, R., Maurice-Bourgoin, L., Dunne, T., Montgomery, D. R., Nittrouer, C. A., and Guyot, J. L.: Episodic sediment accumulation on Amazonian flood plains influenced by El Nino/Southern Oscillation, Nature, 425, 493-497, 2003.

Aalto, R. and Nittrouer, C. A.: 210Pb geochronology of flood events in large tropical river systems, Philos. T. R. Soc. Lond. A, 370 , 2040-2074, 2012.

Aufdenkampe, A. K., Mayorga, E., Raymond, P. A., Melack, J. M., Doney, S. C., Alin, S. R., Aalto, R. E., and Yoo, K.: Riverine coupling of biogeochemical cycles between land, oceans, and atmosphere, Front. Ecol. Environ., 9, 53-60, 2011.

Battin, T. J., Kaplan, L. A., Findlay, S., Hopkinson, C. S., Marti, E., Packman, A. I., Newbold, J. D., and Sabater, F.: Biophysical controls on organic carbon fluxes in fluvial networks, Nat. Geosci., 1, 95-100, 2008.

Battin, T. J., Luyssaert, S., Kaplan, L. A., Aufdenkampe, A. K., Richter, A., and Tranvik, L. J.: The boundless carbon cycle, Nat. Geosci., 2, 598-600, 2009.

Berhe, A. A., Harte, J., Harden, J. W., and Torn, M. S.: The significance of the erosion-induced terrestrial carbon sink, Bioscience, 57, 337-346, 2007.

Brantley, S. L., Megonigal, J. P., Scatena, F. N., Balogh-Brunstad, Z., Barnes, R. T., Bruns, M. A., Van Cappellen, P., Dontsova, K., Hartnett, H. E., Hartshorn, A. S., Heimsath, A., Herndon, E., Jin, L., Keller, C. K., Leake, J. R., McDowell, W. H., Meinzer, F. C., Mozdzer, T. J., Petsch, S., Pett-Ridge, J., Pregitzer, K. S., Raymond, P. A., Riebe, C. S., Shumaker, K., Sutton-Grier, A., Walter, R., and Yoo, K.: Twelve testable hypotheses on the geobiology of weathering, Geobiology, 9, 140-165, 2011.

Brown, A. G., Carey, C., Erkens, G., Fuchs, M., Hoffmann, T., Macaire, J. J., Moldenhauer, K. M., and Walling, D. E.: From sedimentary records to sediment budgets: Multiple approaches to catchment sediment flux, Geomorphology, 108, 35-47, 2009.

Cerdà, A., Brazier, R., Nearing, M. A., and de Vente, J.: Preface: scales and erosion, Catena, 102, 1-2, 2012.

Chiverrell, R. C., Foster, G. R., Thomas, G. S. P., Marshall, D., and Hamilton, D.: Robust chronologies for landform development, Earth Surf. Proc. Land., 34, 319-328, 2008.

Cole, J. J., Prairie, Y. T., Caraco, N. F., McDowell, W. H., Tranvik, L. J., Striegl, R. G., Duarte, C. M., Kortelainen, P., Downing, J. A., Middelburg, J. J., and Melack, J.: Plumbing the global carbon cycle: Integrating inland waters into the terrestrial carbon budget, Ecosystems, 10, 171-184, doi:10.1007/s10021-006-9013-8, 2007.

Dotterweich, M.: The history of soil erosion and fluvial deposits in small catchments of central Europe: Deciphering the long-term interaction between humans and the environment - A review, Geomorphology, 101, 192-208, 2008.

Dusar, B., Verstraeten, G., Notebaert, B., and Bakker, J.: Holocene environmental change and its impact on sediment dynamics in the Eastern Mediterranean, Earth-Sci. Rev., 108, 137-157, 2011.

Erkens, G., Hoffmann, T., Gerlach, R., and Klostermann, J.: Complex fluvial response to Late Glacial and Holocene allogenic forcings in the Lower Rhine embayment (Germany), Quaternary Sci. Rev., 30, 611-627, 2011.

Edited by: A. Cerdà 
Fuchs, A., Lang, A., and Wagner, G. A.: The history of soil erosion and landscape degradation in the Phlious basin, NE Peleponnes, Greece, The Holocene, 14, 334-345, 2004.

Galy, A., France-Lanord, C., Beyssac, O., Faure, P., Kudrass, H., and Palhol, F.: Efficient organic carbon burial in the Bengal fan sustained by the Himalayan erosional system, Nature, 450, 407410, 2007.

Hilton, R. G., Galy, A., Hovius, N., Chen, M. C., Horng, M. J., and Chen, H.: Tropical-cyclone-driven erosion of the terrestrial biosphere from mountains, Nat. Geosci., 1, 759-762, 2008.

Hobo, N., Makaske, B., Wallinga, J., and Middelkoop, H.: Reconstruction of sedimentation rates in embanked floodplains, a comparison of different methods, Earth Surf. Proc. Land., 35, 1499$1515,2010$.

Hoffmann, T., Erkens, G., Dikau, R., Houben, P., Seidel, J., and Cohen, K. M.: Holocene floodplain sediment storage and hillslope erosion within the Rhine catchment, The Holocene, 17, 105-118, 2007.

Hoffmann, T., Erkens, G., Gerlach, R., Klostermann, J., and Lang, A.: Trends and controls of Holocene floodplain sedimentation in the Rhine catchment, Catena, 77, 96-106, 2009a.

Hoffmann, T., Glatzel, S., and Dikau, R.: A carbon storage perspective on alluvial sediment storage in the Rhine catchment, Geomorphology, 108, 127-137, 2009b.

Hoffmann, T., Thorndycraft, V. R., Brown, A. G., Coulthard, T., Damnati, B., Kale, V. S., Middelkoop, H., Notebaert, B., and Walling, D. E.: Human impact on fluvial regimes and sediment flux during the Holocene: Review and future research agenda, Global Planet. Change, 72, 87-98, 2010.

Hoffmann, T., Schlummer, M., Verstraeten, G., and Notebaert, B.: Significance of sediment and carbon storage on hillslopes and floodplains, Global Biogeochem. Cy., 27, 22013, doi:10.1002/gbc.20071, 2013.

Houben, P.: Scale linkage and contingency effects of field-scale and hillslope-scale controls of long-term soil erosion: Anthropogeomorphic sediment flux in agricultural loess watersheds of Southern Germany, Geomorphology, 101, 172-191, 2008.

Houben, P., Wunderlich, J., and Schrott, L.: Climate and long-term human impact on sediment fluxes in watershed systems, Geomorphology, 108, 1-7, 2009.

Hupp, C. R., Pierce, A. R., and Noe, G. B.: Floodplain geomorphic processes and environmental impacts of human alteration along coastal plain rivers, USA, Wetlands, 29, 413-429, 2009.

Jacinthe, P. A. and Lal, R.: A mass balance approach to assess carbon dixoide evolution during erosion events, Land Degrad. Dev., 12, 329-339, 2001.

Kaplan, J. O., Krumhardt, K., Ellis, E. C., Ruddiman, W. F., Lemmen, C., and Klein Goldewijk, K.: Holocene carbon emissions as a result of anthropogenic land cover change, The Holocene, 21, 775-791, 2011.

Kaplan, J. O., Krumhardt, K. M., and Zimmermann, N. E.: The effects of land use and climate change on the carbon cycle of Europe over the past 500 years, Glob. Change Biol., 18, 902-914, 2012.

Lal, R.: Soil Carbon Sequestration Impacts on Global Climate Change and Food Security, Science, 304, 1623-1627, 2004.

Lal, R.: Soil erosion and carbon dynamics, Soil Till. Res., 81, 137142,2005
Lal, R.: Sequestering carbon in soils of arid ecosystems, Land Degrad. Dev., 20, 441-454, 2009.

Lal, R. and Pimentel, D.: Soil erosion: A carbon sink or source? Science, 319, 1040-1041, 2008.

Lang, A. and Honscheidt, S.: Age and source of colluvial sediments at Vaihingen-Enz, Germany, Catena, 38, 89-107, 1999.

Lang, A., Bork, H.-R., Mäckel, R., Preston, N., Wunderlich, J., and Dikau, R.: Changes in sediment flux and storage within a fluvial system: some examples from the Rhine catchment, Hydrol. Process., 17, 3321-3334, 2003.

Lechterbeck, J., Kalis, A. J., and Meurers-Balke, J.: Evaluation of prehistoric land use intensity in the Rhenish Loessboerde by canonical correspondence analysis - A contribution to LUCIFS, Geomorphology, 108, 138-144, 2009.

Lowdermilk, W. C.: Conquest of the Land through 7,000 Years, Soil Conservation Service, Misc. Pub. No. 32, 1948.

Maselli, V. and Trincardi, F.: Man made deltas, Scientific Reports, 3, 1926, doi:10.1038/srep01926, 2013.

Noe, G. B. and Hupp, C. R.: Carbon, nitrogen, and phosphorus accumulation in floodplains of Atlantic Coastal Plain rivers, USA, Ecol. Appl., 15, 1178-1190, 2005.

Notebaert, B. and Verstraeten, G.: Sensitivity of West and Central European river systems to environmental changes during the Holocene: A review, Earth-Sci. Rev., 103, 163-182, 2010.

Notebaert, B., Verstraeten, G., Ward, P. J., Renssen, H., and Van Rompaey, A.: Modeling the sensitivity of sediment and water runoff dynamics to Holocene climate and land use changes at the catchment scale, Geomorphology, 126, 18-31, 2011.

Osterkamp, W. R., Hupp, C. R., and Stoffel, M.: The interactions between vegetation and erosion: new directions for research at the interface of ecology and geomorphology, Earth Surf. Proc. Land., 37, 23-36, 2012.

Parsons, A. J., Brazier, R., Wainwright, J., and Powell, D. M.: Scale relationships in hillslope runoff and erosion, Earth Surf. Proc. Land., 31, 1384-1393, 2006.

Petrescu, A. M. R., Van Beek, L. P. H., Van Huissteden, J., Prigent, C., Sachs, T., Corradi, C. A. R., Parmentier, F. J. W., and Dolman, A. J.: Modeling regional to global $\mathrm{CH} 4$ emissions of boreal and arctic wetlands. Global Biogeochem. Cy., 24, GB4009, doi:10.1029/2009GB003610, 2010.

Quinton, J. N., Govers, G., Van Oost, K., and Bardgett, R. D.: The impact of agricultural soil erosion on biogeochemical cycling, Nat. Geosci., 3, 311-314, doi:10.1038/ngeo838, 2010.

Ritchie, J. C. and Rasmussen, P. E.: Application of 137Cesium to estimate erosion rates for understanding soil carbon loss on longterm experiments at Pendleton, Oregon, Land Degrad. Dev., 11, 75-81, 2000.

Ruddiman, W. F.: The anthropogenic greenhouse era began thousands of years ago, Climatic Change, 61, 261-293, 2003.

Solomon, S., Qin, D., Manning, M., Chen, Z., Marquis, M., Averyt, K. B., Tignor, M., and Miller, H. L.: Climate Change 2007 The Physical Science Basis. Contribution of Working Group I to the Fourth Assessment Report of the Intergovernmental Panel on Climate Change, Cambridge University Press, Cambridge, 2007.

Starr, G. C., Lal, R., Malone, R., Hothem, D., Owens, L., and Kimble, J. M.: Modeling soil carbon transported by water erosion processes, Land Degrad. Dev., 11, 83-91, 2000. 
Syvitski, J. P. M., Vorosmarty, C. J., Kettner, A. J., and Green, P.: Impact of humans on the flux of terrestrial sediment to the global coastal ocean, Science, 308, 376-380, 2005.

Tranvik, L. J., Downing, J. A., Cotner, J. B., Loiselle, S. A., Striegl, R. G., Ballatore, T. J., Dillon, P., Finlay, K., Fortino, K., Knoll, L. B., Kortelainen, P. L., Kutser, T., Larsen, S., Laurion, I., Leech, D. M., McCallister, S. L., McKnight, D. M., Melack, J. M., Overholt, E., Porter, J. A., Prairie, Y., Renwick, W. H., Roland, F., Sherman, B. S., Schindler, D. W., Sobek, S., Tremblay, A., Vanni, M. J., Verschoor, A. M., von Wachenfeldt, E., and Weyhenmeyer, G. A.: Lakes and reservoirs as regulators of carbon cycling and climate, Limnol. Oceanogr., 54, 2298-2314, 2009.

Trimble, S. W.: Decreased rates of alluvial sediment storage in the Coon Creek Basin, Wisconsin, 1975-93, Science, 285, 12441246, 1999.

Van De Wiel, M. J. and Coulthard, T.: Self-organized criticality in river basins: Challenging sedimentary records of environmental change, Geology, 38, 87-90, 2010.

Van Oost, K., Quine, T. A., Govers, G., De Gryze, S., Six, J., Harden, J. W., Ritchie, J. C., McCarty, G. W., Heckrath, G., Kosmas, C., Giraldez, J. V., da Silva, J. R. M., and Merckx, R.: The impact of agricultural soil erosion on the global carbon cycle, Science, 318, 626-629, 2007.

Van Oost, K., Verstraeten, G., Doetterl, S., Notebaert, B., Wiaux, F., Broothaerts, N., and Six, J.: Legacy of human-induced C erosion and burial on soil-atmosphere C exchange, P. Natl. Acad. Sci., 109, 19492-19497, 2012.
Verstraeten, G., Rommens, T., Peeters, I., Poesen, J., Govers, G., and Lang, A.: A temporarily changing Holocene sediment budget for a loess-covered catchment (central Belgium), Geomorphology, 108, 24-34, 2009.

Victoria, R., Banwart, S., Black, H., Ingram, J., Joosten, H., Milne, E., and Noellemeyer, E.: The benefits of soil carbon. Managing soils for multiple economic, societal and environmental benefits, in: The UNEP years books 2012, edited by: UNEP, 19-33, 2012.

Walter, R. C. and Merritts, D. J.: Natural streams and the legacy of water-powered mills, Science, 319, 299-304, 2008.

Wang, Z., Govers, G., Steegen, A., Clymans, W., Van den Putte, A., Langhans, C., Merckx, R., and Van Oost, K.: Catchment-scale carbon redistribution and delivery by water erosion in an intensively cultivated area, Geomorphology, 124, 65-74, 2010.

Wilkinson, B. H. and McElroy, B. J.: The impacts of humans on continental erosion and sedimentation, Geol. Soc. Am. Bull., 119, 140-156, 2007.

Yoo, K., Ji, J., Aufdenkampe, A. K., and Klaminder, J.: Rates of soil mixing and associated carbon fluxes in a forest versus tilled agricultural field: Implications for modeling the soil carbon cycle, J. Geophys. Res.-Biogeo., 116, GB3003, doi:10.1029/2004GB002271, 2011.

Zehetner, F., Lair, G. J., and Gerzabek, M. H.: Rapid carbon accretion and organic matter pool stabilization in riverine floodplain soils, Global Biogeochem. Cy., 23, GB4004, doi:10.1029/2009GB003481, 2009. 